\title{
Tomasz Rakoczy
}

\section{Relacja podmiotu do obowiązku w orzekaniu nieważności małżeństwa z kan. 1095 n. 3 KPK}

Prawo Kanoniczne : kwartalnik prawno-historyczny 53/1-2, 181-201

2010

Artykuł został opracowany do udostępnienia w internecie przez Muzeum Historii Polski w ramach prac podejmowanych na rzecz zapewnienia otwartego, powszechnego i trwałego dostępu do polskiego dorobku naukowego i kulturalnego. Artykuł jest umieszczony w kolekcji cyfrowej bazhum.muzhp.pl, gromadzącej zawartość polskich czasopism humanistycznych i społecznych.

Tekst jest udostępniony do wykorzystania w ramach dozwolonego użytku. 


\section{RELACJA PODMIOTU DO OBOWIĄZKU W ORZEKANIU NIEWAŻNOŚCI MAŁŻEŃSTWA Z KAN. 1095 N. 3 KPK}

Treść: Wstęp. - 1. Relacja do istotnego obowiązku małżeńskiego. - 2. Specyfika relacji do obowiązku. - 2.1. Niezdolność do podjęcia, a nie niezdolność do wypełnienia. - 2.2. Niezdolność podmiotu do obowiązku, a nie niezdolność pary małżeńskiej do wzajemnego życia - niezdolność obiektywna a nie relatywna. - 3. Podstawa relacji. - 3.1. Zadanie biegłego. - 3.2. Zadanie trybunału. - Wnioski.

Prawodawca powszechny w kan. 1095 n. 3 KPK wskazuje, że niezdolnymi do ważnego zawarcia małżeństwa są ci, którzy z przyczyn natury psychicznej nie są zdolni podjacć istotnych obowiązków małżeńskich: Sunt incapaces matrimonii contrahendi qui ob causas naturae psychicae obligationes matrimonii essentiales assumere non valent.

H. Stawniak i G. Dzierżon, dokonując analizy treściowej wskazanego kanonu, wyliczają w nim trzy elementy: niezdolny, przyczyny natury psychicznej, istotne prawa i obowiązki małżeńskie'.

Mając na uwadze temat niniejszego artykułu, można postawić tezę, że kluczowym zagadnieniem dla orzekania o niezdolności podmiotu do podjęcia istotnych obowiązków małżeńskich jest relacja, jaka zachodzi między podmiotem, a obowiązkiem. Przesłanką skłaniającą do przyjęcia takiej tezy może być fakt, że trybunał kościelny, dochodzi do orzeczenia o nieważności małżeństwa na podstawie udowodnienia wadliwej relacji, jaką wytwarza podmiot do obowiązku małżeńskiego. Celem niniejszego artykułu jest zebranie istotnych wymagań prawodawcy powszechnego odnośnie do relacji zachodzącej między

${ }^{1}$ H. S t a w n i a k, Niezdolność do podjęcia istotnych obowiazków matżeńskich z przyczyn natury psychicznej (n. 3 kan. 1095 KPK), PK 48 (2005) nr 1 - 2, s. 36; G. D z i e r ż o n, Niezdolność do zawarcia matżeństwa jako kategoria kanoniczna, Warszawa 2002, s. 206. 
podmiotem a obowiązkiem, a świadczącej o nieważności małżeństwa. Stąd można dokonać innego podziału normy kan. 1095 n. 3 i wyróżnić w niej inne elementy strukturalne. Są nimi: podmiot niezdolności (podobnie, jak w poprzednim podziale - „niezdolny”), obowiązek małżeński (podobnie, jak w poprzednim podziale) i relacja do obowiązku (a nie tylko ,z przyczyn natury psychicznej”, co stanowi jedynie fundament nieprawidłowej relacji, ale nie określa jej wyczerpująco).

Przyjęcie takiego podziału, stanowi o dobrze zredagowanej skardze powodowej. Strona powodowa, skarżąc swoje małżeństwo, powinna wyraźnie nakreślić te trzy elementy. Winna zatem jasno wskazać: kto jest niezdolny (czy ona sama, czy druga strona małżeństwa, czy też obydwoje małżonkowie), po drugie o jaki obowiązek małżeński chodzi (że jest on istotny) i wreszcie po trzecie na czym polega owa niezdolność, czyli opisać relację podmiotu do obowiązku. Z treści skargi powodowej musi się już więc wyraźnie wyłaniać uzasadniona sugestia, że relacja podmiotu do jakiegoś istotnego obowiązku małżeńskiego była przynajmniej poważnie zachwiana. Tym bardziej wskazane trzy elementy winny zostać jasno ukazane w wyroku sądowym.

Na charakterystykę relacji złożą się następujące zagadnienia: relacja do istotnego obowiązku małżeńskiego, specyfika relacji do obowiązku i podstawa relacji.

\section{Relacja do istotnego obowiązku małżeńskiego}

Pojęcie istotnych obowiązków małżeńskich nie stanowi katalogu zamkniętego. Wprost przeciwnie, jest on rzeczywistością dynamiczna. Nawet skonstruowanie takiej zamkniętej listy stanowiłoby zubożenie rzeczywistości małżeństwa. Można jedynie wskazać na przykładowy katalog takich obowiązków, co czyni się wciąż w doktrynie prawa kanonicznego ${ }^{2}$. Takie katalogi moga jednak stanowić tylko pewną, ale z drugiej strony, istotną pomoc. Rota Rzymska, jak twierdzi Paździor w swoim opracowaniu z 1999 r., nie podała pełnego katalogu istotnych

${ }^{2}$ Zob. J. C y m b a ł a, Istotne obowiqzki matżeńskie i przyczyny niezdolności do ich podjeccia $w$ wyrokach Roty Rzymskiej z lat 1983-1992 wydanych na podstawie kan. 1095 n. 3 Kodeksu Prawa Kanonicznego opublikowanych w Decisiones, Olsztyn 2002, s. 36-66. 
praw i obowiązków małżeńskich ${ }^{3}$. Ten fakt może stanowić jedynie potwierdzenie słuszności tezy o dynamicznym charakterze małżeństwa.

$Z$ racji na wskazaną niemożność skonstruowania zamkniętego katalogu obowiązków i praw małżeńskich, warto poszukać ich fundamentu. KKK, powtarzając kan. $1055 \mathrm{KPK}$, będący definicją małżeństwa uczy, że: „Przymierze małżeńskie, przez które mężczyzna i kobieta tworzą ze sobą wspólnotę całego życia, skierowaną ze swej natury na dobro małżonków oraz do zrodzenia i wychowania potomstwa, zostało między ochrzczonymi podniesione przez Chrystusa Pana do godności sakramentu"4. Z powyższej definicji wynika, że małżeństwo jest przymierzem, czyli wspólnotą zawartą przez mężczyznę i kobietę, która obejmuje całe ich życie. Ta całość życia małżonków nie dotyczy głównie czasu trwania związku małżeńskiego, ale przede wszystkim wszelkich wymiarów wspólnego życia. Te z kolei konkretyzują się we wzajemnych prawach i obowiązkach przyjmowanych i przekazywanych. Stąd też w celach małżeństwa (dobro wspólne małżonków oraz zrodzenie i wychowanie potomstwa) i w jego przymiotach (jedność, nierozerwalność i sakramentalność) należy upatrywać fundamentu istotnych obowiązków małżeńskich ${ }^{5}$. Ten fundament W. Góralski nazywa przedmiotem formalnym małżeństwa ${ }^{6}$.

W procesie o nieważność małżeństwa należy mieć na uwadze to, aby badać relację do istotnego obowiązku małżeńskiego, czyli takiego, który wyrasta ze wskazanego fundamentu. Obok obowiązków istotnych, które jedynie mogą wchodzić tu w grę, w sferze życia małżeńskiego, istnieje cała gama obowiązków, które nie mogą pretendować do takiego miana. O ile w literaturze kanonistycznej spotyka się katalogi obowiazzów istotnych (o czym była mowa poprzednio), o tyle pomija się milczeniem te, jakie z całą pewnością można by uznać za nieistotne, a wciąż będące obowiązkami małżeńskimi. Skonstruowanie takiego, chociażby przykładowego katalogu, stanowiłoby bez wątpienia istotna pomoc dla kościelnego wymiaru sprawiedliwości. Odwołanie się do

${ }^{3}$ S. P a ź d z i o r, Przyczyny psychiczne niezdolności osoby do zawarcia matzeństwa $w$ świetle kan. 1095, Lublin 1999, s. 27.

${ }^{4}$ KKK 1603.

${ }^{5}$ H. S t a w n i a k, Niezdolność do podjęcia ..., s. 44-45; W. G ó r a $1 \mathrm{~s} \mathrm{k} \mathrm{i,}$ Niezdolność do zawarcia matżeństwa wedtug kan. 1095 nn. 1 - 3 KPK. Próba syntezy, PK 39 (1996) nr 3-4, s. 35.

${ }^{6}$ W. G ó r a 1 s k i, Kanoniczne prawo małżeńskie, Warszawa 2000, s. 38-39. 
niego w wyroku trybunału kościelnego, stanowiłoby istotny argument dla powstrzymania się od orzekania o nieważności małżeństwa, nie tyle z powodu braku stwierdzenia ,przyczyn natury psychicznej”, ile z powodu braku podstawy. Steuden, patrząc z perspektywy psychologii, jako przykłady obowiązków nieistotnych wskazuje: niezgodność i konflikty między małżonkami i ich rodzicami. Takie - jak uważa wskazana autorka - obserwuje się szczególnie na wsi u młodych małżeństw zamieszkałych u swoich rodziców, dzielących z nimi gospodarstwa ${ }^{7}$.

\section{Specyfika relacji do obowiązku}

W ukazaniu tego, czego żąda prawo kanoniczne od relacji, by świadczyła o nieważności małżeństwa, można wskazać zarówno na wyróżniki o sensie pozytywnym, jak i negatywnym. Zostały one wypracowane w prawie kanonicznym, poprzez normy prawne i orzecznictwo, a następnie rozwinięte w doktrynie.

Jeśli chodzi o wymiar negatywny, to należy unikać dowodzenia niezdolności do wypełnienia obowiązku małżeńskiego, a także tzw. niezdolności relatywnej. Odrzucając te dwa negatywne wymiary, wymagana przez prawo kanoniczne niezdolność polegać będzie na: niezdolności do podjęcia przez podmiot obowiązku małżeńskiego oraz po wtóre na obiektywnej niezdolności podmiotu, to znaczy takiej, która jest wolna i niezależna od wpływu czynników zewnętrznych, w tym drugiej strony małżeństwa.

2.1. Niezdolność do podjęcia a nie niezdolność do wypełnienia

W tekście łacińskim kanonu 1095 n. 3 KPK prawodawca użył terminu: incapacitas assumendi, co oznacza niezdolność do podjęcia. Nie ma zatem mowy o niezdolności, jaką można by określić poprzez incapacitas adimplendi, co należałoby tłumaczyć jako niezdolność do wypełnienia. Z tej prostej analizy pojęć użytych przez prawodawcę, wynika, że w badaniu niezdolności należy zmierzać do badania niezdolności do podjęcia, a nie niezdolności do wypełnienia ${ }^{8}$. Tym bardziej nie wolno mieszać ze sobą obu tych - jak zostanie to wykazane - różnych po-

7 S. S t e u d e n, Zadania psychologa $w$ sprawach o stwierdzenie nieważności małżeństwa, w: Z. Płużek, Psychologia pastoralna, Kraków 1991, s. 213.

${ }^{8}$ F. P o m p e d d a, Kan. 1095 w systematyce generalnej KPK $i$ w ewolucji interpretacyjnej, Ius Matrimoniale 4 (1999), s. 41. 
jęć i co ważniejsze różnych zdolności ich dotyczących ${ }^{9}$. Miarodajna dla sądu kościelnego jest jedynie niezdolność do podjęcia istotnych obowiązów małżeńskich, co z drugiej strony nie zawsze musi być przeciwne zdolności do wypełnienia. Zagadnienie to jest bardzo ważne z racji na to, że operuje się często obydwoma tymi pojęciami.

Chodzi więc o to, aby zbadać i wykazać, że podmiot nie jest w stanie „wystartować do" jakiegoś istotnego obowiązku małżeńskiego. Jeśli nawet nie byłby on w stanie wypełnić takiego obowiązku, ale w jego postawie byłyby zauważalne zdolności do owego „wystartowania do”, to ewentualnie można by mówić o niezdolności do wypełnienia, co jednak nie jest treścią kan. 1095 n. 3 i konsekwentnie nie świadczy o nieważności małżeństwa.

Niezdolność do podjęcia można przyrównać do sytuacji niemowlęcia, które dotychczas chodzi na czworakach i w swoim rozwoju fizjologicznym nie ma jeszcze zdolności ku temu, aby nawet spróbować podnieść się i stanąć na nogach. W tej fazie swojego życia niemowlę w ogóle nie jest „zainteresowane” wstawaniem na dwie nogi, nie ma w sobie zdolności do „wystartowania do" tego nowego, czekającego go obowiazku. Nawet zachęcane i pobudzane do niego przez inne czynniki, wciąż pozostaje „niewzruszone”. Można powiedzieć o nim, że nie ma w sobie zdolności do tego, by wstawać (nawet nie wstać, tylko wstawać). Stosując do niego ,instumentarium pojęciowe kan. 1095 n. 3", można mówić o niezdolności do podjęcia nowego obowiązku i w konsekwencji (ale tylko w konsekwencji) do wypełnienia go.

$\mathrm{Z}$ czasem dopiero pojawią się w życiu dziecka pierwsze wysiłki. Jak należy się spodziewać, zgodnie z jego rozwojem, będą one udaremniane, bo wciąż ta nowa sytuacja okaże się zbyt trudna. Oceniając zachowanie niemowlęcia, próbującego wstać, stosując do niego owo „instrumentarium pojęciowe kan. 1095 n. 3”, można powiedzieć, że dziecko jest zdolne do podjęcia nowego obowiązku, ponieważ podejmuje wysiłki ku niemu, „startuje do tego nowego obowiązku”, mimo że przychodzi mu to $\mathrm{z}$ trudem. Niemowlę wciąż jest jednak niezdolne do wypełnienia nowego obowiązku, bo wciąż mu to nie wychodzi. Przy podjęciu wysiłku i pokonaniu trudów będzie kiedyś zdolne do jego wypełnienia i de facto wypełni go. Na tym etapie widać więc wy-

\footnotetext{
${ }^{9}$ H. S t a w n i a k, Niezdolność do podjęcia ..., s. 36-37.
} 
raźnie, że dziecko nie jest zdolne do wypełnienia obowiązku, ale jest zdolne do jego podjęcia.

Idąc dalej w tej dywagacji, patrząc ściśle na obie niezdolności (do podjęcia i do wypełnienia) można umiejscowić je na dwóch krańcach kontinuum: na jednym z nich należy zamieścić niezdolność do podjęcia, a na drugim niezdolność do wypełnienia. Można więc pytać: czy ewentualne, zauważalne wysiłki podmiotu świadczą o zdolności do podjęcia, chociaż jeszcze nie do wypełnienia, czy są one tak mizerne, że świadcząjuż o niezdolności do podjęcia. Wydaje się, że ocena takiej sytuacji i znalezienie jasnej granicy między niezdolnością do podjęcia, a niezdolnością do wypełnienia, może być uwarunkowana w dużym stopniu przez osąd subiektywny i co za tym idzie, może nie być uchwytna obiektywnie. Takie spostrzeżenie wprowadza zatem pewną trudność w orzekaniu o nieważności małżeństw z kan. 1095 n. 3 KPK i stanowi postulat do dalszego, pogłębionego studium.

Jak zauważa W. Góralski, brak wypełniania obowiązków nie zawsze musi wskazywać na niezdolność z przyczyn natury psychicznej. Z kolei ich wypełnienie jest konsekwencją ich podjęcia i zdolności do ich podjęcia. Nie wypełnianie obowiązków może wskazywać na to, że podmiot zaniedbał szereg środków, które były do jego dyspozycji i nie podjął się trudu przezwyciężenia trudności, które były dla niego możliwe do wykonania albo po prostu nie chciał ich wypełnić. Z tego zatem wynika - jak dowodzi W. Góralski - że niezdolność do podjęcia zakłada rzeczywistą niemożność ,świadczenia obowiązków małżeńskich”. Niezdolność oznacza zatem niemożliwość dla podmiotu ${ }^{10}$.

W wyrokach ferowanych przez Rotę Rzymską przytacza się szereg pojęć mających zobrazować tę niezdolność. Mówi się mianowicie o: niemożliwości moralnej (impossibilitas moralis), niemożliwości moralnej oraz psychicznej (impossibilitas moralis ac psychica), niemożliwości subiektywnej (impossibilitas subiectiva) albo niemożliwości prawnej (impossibilitas iuridica) ${ }^{11}$.

${ }^{10}$ Zob. W. G ó r a $1 \mathrm{~s} \mathrm{k} \mathrm{i,} \mathrm{Niezdolność} \mathrm{konsensualna} \mathrm{do} \mathrm{zawarcia} \mathrm{matżeństwa} \mathrm{ka-}$ nonicznego, Warszawa 2001, s. 198-199; H. S t a w n i a k, Niezdolność do podjęcia..., s. 37.

${ }^{11}$ Zob. G. D z i e r ż o n, Niezdolność do zawarcia matżeństwa ..., s. 206-207. 
2.2. Niezdolność podmiotu do obowiązku, a nie niezdolność pary małżeńskiej do wzajemnego życia - niezdolność obiektywna a nie relatywna

Pojęcie niezdolności relatywnej bynajmniej nie ma swojego podłoża w koncepcjach pochodzących spoza „łona Kościoła”. Wręcz przeciwnie, swój fundament czerpie z personalizmu chrześcijańskiego, zarysowanego przez Sobór Watykański II. Podkreśla się w nim, że człowiek może w pełni odnaleźć siebie jedynie w szczerym oddaniu w darze samego siebie ${ }^{12}$. Tak ukazana koncepcja spotkała się początkowo z opinią o swojej wystarczalności i co za tym idzie z przyjęciem. Stąd na jej bazie orzekano o nieważności małżeństw. Jej wystarczalność dowiódł min. Ruiz. W swoim wyroku z dnia 5 kwietnia 1973 wskazał, że osoba, chociaż nie jest dotknięta żadnym poważnym zakłóceniem osobowości, to jednak może być niezdolna do nawiązania relacji międzyosobowych z konkretną osobą - swoim małżonkiem ${ }^{13}$.

W pewien czas po przyjęciu koncepcji niezdolności relatywnej, poddano ją analizie i uznano za niewystarczalną. W jej krytyce podniesiono to, że nie wskazuje się na konieczność poważnej anomalii psychicznej u nupturienta. Funghini w swoim wyroku z dnia 23 kwietnia 1993, a zatem już po promulgacji obowiązującego Kodeksu, wyliczył argumenty, dla których taka niezdolność wymaga odrzucenia. Wskazał wśród nich to, że: jedna ze stron winna być dotknięta niezdolnością niezależnie od drugiej; niezdolność nie może być sumą niewielkich patologii obu stron; niezdolność winna odnosić się do istotnych obowiązków małżeńskich i mieć swoje źródło w przyczynach natury psychicznej - nie może natomiast odnosić się do osoby drugiego małżonka; należy badać osobę odnośnie do jej ewentualnej niezdolności w momencie zawierania przez nią związku małżeńskiego, a ze wspólnego życia można jedynie przyjąć argument potwierdzający zakłócenie czy anomalie psychiczną, co jednak nie może być argumentem wiodącym ${ }^{14}$.

12 GS 48.

13 Zob. W. G ó r a $1 \mathrm{~s}$ k i, Problem niezdolności relatywnej do podjęcia istotnych obowiazków małżeńskich (kan. 1095 n. 3 KPK) w świetle orzecznictwa Roty Rzymskiej, Ius Matrimoniale 3 (1998), s. 75-87.

14 Zob. W. G ó r a 1 s k i, Problem niezdolności relatywnej ..., s. 75-87. 
Paździor przytacza opinie wybitnych kanonistów, którzy potwierdzali wystarczalność niezdolności relatywnej. Wskazany autor nie zaznacza jednak, co wynika $\mathrm{z}$ analizy zamieszczonych przez niego przypisów, że wypowiedzi te odnoszą się do orzeczeń sprzed promulgacji nowego Kodeksu ${ }^{15}$.

Idąc za wykładnią kan. 1095 n. 3 obowiązującego Kodeksu, należy jednoznacznie wskazać, że prawodawca ukazuje relację podmiotu do obowiązku, a nie podmiotów wzajemnie do siebie. Przez taką strukturę normy prawnej jednoznacznie odrzuca niezdolność relatywną, a opowiada się za niezdolnością obiektywną. Takie stanowisko podtrzymuje orzecznictwo rotalne i doktryna ${ }^{16}$, chociaż F. Pompedda niezdolność relatywną uważa za „problem delikatny”"17. Jak wynika ze wskazanych w poprzednim punkcie artykułu nazw niezdolności, Rota Rzymska posługuje się także pojęciem niezdolności subiektywnej czy niezdolności moralnej. Nazwy te sugerują raczej niezdolność relatywną, a nie obiektywną. Te delikatne sygnały zdają się sugerować, że niezdolność relatywna być może nie odeszła całkowicie do lamusa.

Niniejsze zagadnienie jest szczególnie ważne w przypadku procesów, w których o niezdolność do podjęcia istotnych obowiązków małżeńskich oskarża się obie strony małżeństwa. W koncepcji niezdolności relatywnej - jak wynika z powyższego - przyjmuje się istnienie niezdolności samej pary małżonków do tego rodzaju relacji. Zakłada się zatem patologię samej wspólnoty małżeńskiej, abstrahując od stwierdzenia ewentualnej niezdolności każdego z małżonków do podjęcia obowiązków małżeńskich. Taka niezdolność polega na tym, że choć żadna ze stron małżeństwa nie jest dotknięta patologią osobowości, to jednak z powodu pewnej przeszkody, osoby te nie mogą ustanowić żadnej innej więzi między sobą, jak tylko więź patologiczną. Zwolennicy niezdolności relatywnej nigdy nie odnoszą się do relacji poszczególnych podmiotów do obowiązków małżeńskich (co nakazuje prawo kanoniczne w kan. 1095 n. 3), ale opisują według doktryny terapeutycznej, jak poszczególne pary małżeńskie zmierzają do tworzenia

15 S. P a ź d z i o r, Przyczyny psychiczne ..., s. 63-64.

16 Zob. H. S t a w n i a k, Niezdolność do podjęcia ..., s. 40.

17 F. P o m p e d d a, Kan. 1095 w systematyce generalnej ..., s. 42. 
jedności spolaryzowanej np. sadysta - masochista, dominujący - podległy, zdrowy - chory, niezależny - zależny ${ }^{18}$.

Chociaż istnieje prawdopodobieństwo, że obydwoje z małżonków, którzy tworzą parę patologiczną nie są zdolni do podjęcia obowiązków małżeńskich, to należy zawsze zmierzać do wykazania relacji do obowiązków małżeńskich u każdego z nich oddzielnie. Dla prawa kanonicznego nie jest miarodajne wskazanie, że więź tworzona przez małżonków, jest patologiczna.

Należy więc zachować daleką wstrzemięźliwość wobec wniosków, jakie mogą być formułowane $\mathrm{w}$ ocenie materiału dowodowego, że strony małżeństwa znały się już od kilku lat przed ślubem i już wówczas wzajemnie funkcjonowały. $Z$ takiego sformułowania zdaje się ma płynąć wniosek, jakoby wypełnianie przez każde z nich obowiązków małżeńskich było sprawdzone czy wypróbowane w przeszłości i w konsekwencji miało osłabiać przekonanie sędziego, by ten opowiedział się za nieważnością małżeństwa. Tymczasem wcześniejsza, nawet długotrwała znajomość stron może niczego nie dowodzić. Strony mogą dobrze funkcjonować $\mathrm{w}$ okresie przedmałżeńskim jako para albo jako znajomi, przyjaciele czy współpracownicy w pracy. Nie maja wówczas za zadanie podejmować obowiązków małżeńskich. Mogą także przez cały czas swojej znajomości przedślubnej funkcjonować patologicznie i czuć się ze sobą dobrze. Co więcej nikt z takiej pary nie zaskarży nieważności swojego małżeństwa, chociaż tak naprawdę nie będą tworzyły ważnego małżeństwa, bo nie będą podejmowały istotnych obowiązków małżeńskich czy to $\mathrm{z}$ racji na dobrowolne wykluczenie, czy obiektywną niezdolność. Od momentu, gdy stają się małżeństwem, należy zbadać relację każdego z nich do sfery obowiązków małżeńskich, a nie ich relację wzajemną do siebie.

Obok tak oczywistych par patologicznych, jakie zostały wskazane poprzednio, mogą istnieć jeszcze inne przypadki, także odpowiadające niezdolności relatywnej. Chodzi mianowicie o sytuacje, w których brak podejmowania obowiązków małżeńskich przez jedną ze stron małżeństwa tłumaczy się negatywnym wpływem drugiej strony. Praktycznym przełożeniem takiej koncepcji może być np. wskazywanie na różnicę

${ }^{18}$ W. G ó r a 1 s k i, Matrimonium facit consensus. Z orzecznictwa Roty Rzymskiej w sprawach o nieważność malżeństwa z tytułów dotyczacych zgody malżeńskiej (1984 - 1997), Warszawa 2000, s. 131-133. 
charakterów (co w konsekwencji miałoby prowadzić do rozpadu małżeństwa). Skuteczność wpływu jednego małżonka na drugiego znajduje swoje usprawiedliwienie np. w psychologii behawioralnej (jest zatem metodycznie usankcjonowana i tym samym warta uwagi), która warunkuje funkcjonowanie podmiotu od wpływu czynników zewnętrznych ${ }^{19}$. Kozielecki w swoim opracowaniu, wyjaśniając teorię behawioralną wskazuje, że środowisko, w którym żyje człowiek jest konfiguracją czy mozaiką bodźców (w skrócie S). Uważa, że bodźce te sterują reakcjami człowieka (w skrócie R). Stąd zachowanie R stanowi funkcję układu zewnętrznych bodźców $\mathrm{S} 1, \mathrm{~S} 2, \ldots \mathrm{SN}$, czyli $\mathrm{R}=\mathrm{f}$ $(\mathrm{S} 1, \mathrm{~S} 2, \ldots \mathrm{SN})$. W tym ujęciu jednostka jest całkowicie kontrolowana przez zewnętrzne zdarzenia. Wskazany autor ilustruje tę teorię, zestawiając ze sobą postawy dwóch różnych robotników. Robotnik wytwarzający narzędzia metodą warsztatową będzie, jego zdaniem, reagował zupełnie inaczej, niż robotnik pracujący przy taśmie automatycznej. Praca warsztatowa, z zasady będąc mniej zmechanizowana, pozwala na regulowanie tempa operacji, rozwija samodzielność i kontakty osobiste między kolegami. Natomiast praca przy taśmie, radykalnie upraszczając ludzkie reakcje, powoduje, że człowiek zaczyna funkcjonować jak automat ${ }^{20}$.

Rozważając psychologię behawioralną, można wskazać tylko to, że podmiot wskutek wpływających na niego bodźców zewnętrznych, nie podejmuje istotnych obowiązków małżeńskich, a nie, że nie ma ku temu obiektywnej zdolności. To jest jeszcze za mało, jeśli chodzi o wymagania prawodawcy z kan. 1095 n. 3 KPK. Nie należy z góry przesądzać sytuacji przeciwnej, czyli takiej gdy wpływ jednej osoby na druga jest takiego stopnia, ze pozbawia obiektywnej zdolności. Taka sytuacja może mieć miejsce, gdy strony małżeństwa znały się przez długi czas przed zawarciem związku. Wpływ jednej strony na drugą jeszcze w okresie przedmałżeńskim, mógł ukształtować w tej drugiej postawę niezdolności do podjęcia przyszłych obowiązków małżeńskich. Ta pierwsza strona mogła okazać się bardziej dominująca i swoją postawą wygasiła w drugiej obiektywną zdolność. Taką hipotezę należałoby

19 P. O l e ś, Wprowadzenie do psychologii osobowości, Warszawa 2003, s. 167170.

20 Zob. J. K o z i e 1 e c k i, Koncepcje psychologiczne człowieka, Warszawa 1998, s. 21-89. 
jeszcze zweryfikować przez inne dowody, ale jak się wydaje nie jest ona całkowicie bezpodstawna.

W świetle powyższych analiz, wydaje się, że można postawić tezę, że trybunał „zdaje praktyczny egzamin” z orzekania o niezdolności, jeśli podmiot został uznany za obiektywnie niezdolnego do podjęcia obowiazków małżeńskich w konkretnym związku, po czym zawarł następny związek (który nastapił krótko po pierwszym) i jego funkcjonowanie także napotkało na te same błędy. Byłoby natomiast niepokojące, gdyby okazało się, że w innym małżeństwie tenże podmiot podejmuje obowiązki małżeńskie, a ten inny związek nie został zawarty krótko po rozpadzie wcześniejszego małżeństwa (co wykluczyłoby proces pewnego dojrzewania czy podjęcia pracy nad sobą w celu pokonania przyczyny natury psychicznej). Po obserwacji takiego zachowania, można by postawić hipotezę, że trybunał orzekł niezdolność relatywną, a nie obiektywną takiego podmiotu.

\section{Podstawa relacji}

Podstawą, powodująca niezdolność, a zatem owym fundamentem normy kan. 1095 n. 3 KPK może być jedynie zdiagnozowana anomalia $^{21}$. Na temat konieczności jej stwierdzenia w wyrokowaniu z kan. 1095 n. 3 KPK wypowiedział się autorytatywnie Jan Paweł II do Roty Rzymskiej w alokucji z dnia 5 lutego 1987, w którym stwierdził, że: „prawdziwa niezdolność jest możliwa do wyobrażenia, jedynie w przypadku poważnej anomalii, którą jakkolwiek chciałoby się określić, to musi ona naruszać istotowo zdolność rozumienia i/lub pragnienia kontrahentów"22. Jan Paweł II w przemówieniu, które wygłosił rok później - 25 stycznia 1988 - dodał, że szacowanie owej niezdolności nie może mieć miejsca w stosunku do ideału życia małżeńskiego, ale odnośnie do zdolności minimalnej ${ }^{23}$. Tylko więc osoba nie będąca w stanie podejmować obowiązków małżeńskich czy też jednego z nich w płaszczyźnie pewnego minimum, może być uznana w ostateczności za niezdolną z kan. 1095 n. 3 KPK. Ta niezdolność mieści się między dwoma skrajnymi punktami, które wytycza się z racji na to, że po pierwsze małżeństwo odpowiada naturze człowieka, i że każdy czło-

${ }^{21}$ F. P o m p e d d a, Kan. 1095 w systematyce ..., s. 41.

22 Por. tekst polski za: T. R o z k r u t (red.), Jan Pawet II do Roty Rzymskiej (1979 - 2003), Tarnów 2003, s. 116.

${ }^{23}$ Tekst polski za: T. R o z k r u t (red.), Jan Paweł II do Roty Rzymskiej..., s. 128. 
wiek $\mathrm{z}$ racji na swoją naturę jest $\mathrm{w}$ stanie zawrzeć małżeństwo. Po drugie, małżeństwo, nie może być tylko dla ludzi mających wysoko rozwinięte władze poznawcze. W ślad za tym założeniem podąża prawo kanoniczne, ustanawiając normy, które zakładają możliwość podmiotu do zawarcia małżeństwa i sankcjonują stan kondycji ludzkiej, w której podejmowanie obowiązków małżeńskich nie jest dla podmiotu czymś przerastającym jego siły ${ }^{24}$.

Zwrot użyty w konstrukcji normy kan. 1095 n. 3 KPK ,z przyczyn natury psychicznej" oznacza, iż niezdolność musi odnosić się do struktury psychicznej podmiotu, niezależnie od przyczyny, jaka ją wywołała, np. na bazie organicznej ${ }^{25}$. Wskazany uprzednio przykład niemowlęcia nie mogącego wstać, chociaż obrazuje niezdolność do podjęcia, to opiera się na tym, że dziecko z racji fizjologicznych nie osiagnęło jeszcze należytego stopnia zdolności. Jest ono na to zbyt młode, aby mówić w jego życiu o anomalii. Idąc ściśle za tym spostrzeżeniem, u osoby, której osobowość byłaby w podobnej kondycji, co wskazane niemowlę, można by postawić hipotezę o braku rozeznania oceniającego. Wysunięty przykład skłania do wskazania dwóch istotnych różnic między normą zawartą w n. 2 i 3 kan. 1095 KPK i tym samym do ukazania dalszych wymagań odnośnie do podstawy relacji. Po pierwsze, prawodawca powszechny, w normie kan. 1095 n. 2 KPK, w której stanowi o poważnym braku rozeznania oceniającego, nie wskazuje na konieczność anomalii, wręcz zbywa milczeniem - w odróżnieniu od kan. 1095 n. 3 KPK - podstawy braku takiego rozeznania. O ile zatem w n. 3 domaga się stwierdzenia przyczyn psychicznych, o tyle w n. 2 już nie. Taki stan prawny powodował zgłaszanie postulatów, aby znieść wymóg normy kan. 1095 n. 3 i wykreślić sformułowanie ,z przyczyn natury psychicznej". Zamysł wprowadzenia tej nowelizacji miał na celu swojego rodzaju wyrównanie kategorii obu norm (tj. z nr 2 i 3$)^{26}$. Po wtóre, na co zwrócił uwagę Pinto w swoim często cytowanym przemówieniu z 1979, w interpretacji kan. 1095 n. 2 KPK wskazuje się, że dla stwierdzenia braku rozeznania oceniającego miarodajne jest konkretne „tu i teraz małżeńskiego życia”. Natomiast w przypadku kan. 1095 n. 3 KPK, należy mieć na uwadze nie charakter czasowy (pewno

${ }^{24}$ R. S o b a ń s k i, Dylematy przy stosowaniu kanonu 1095, PK 48 (2005) nr 1-2, S. 50 .

25 W. G ó r a 1 s k i, Niezdolność do zawarcia matżeństwa ..., s. 33.

26 Tamże, s. 34. 
będący wyrazem jakiejś relatywności) wady zgody, ale trwałość, istniejącą przynajmniej w momencie zawarcia małżeństwa ${ }^{27}$.

Propozycja dokonania wspomnianej nowelizacji kan. 1095 n. 3 KPK nie została jednak przyjęta. W przeciwnym przypadku, jak należałoby się spodziewać, odstapiono by od istoty problemu. Tak szeroko rozumiane racje natury psychicznej nie stanowiłyby o obiektywnej niezdolności podmiotu, co jest sensem normy prawnej. W konsekwencji, orzekanie nieważności małżeństwa z jakichkolwiek mankamentów osobowościowych spowodowałoby totalnie zliberalizowanie instytucji małżeństwa (rozmywając przymiot nierozerwalności) albo wprost przeciwnie - skutkowałoby ukazaniem jego wyjątkowego charakteru, jako instytucji możliwej tylko dla niektórych.

Innym następstwem przyjęcia zasady, że obiektywna niezdolność dotyka tylko osób dotkniętych anomalią osobowości, jest to, że istnieje cały szereg „przypadków ludzkich”, u których istnieją mankamenty osobowościowe „mniejszego rodzaju”, jakie nie pretenduja do owej podstawy, którą są przyczyny natury psychicznej rozumiane w sensie autorytatywnej wypowiedzi Jana Pawła II. Dlatego w przypadku takich osób, konsekwentnie nie wolno orzekać o nieważności ich małżeństwa. Do orzekania o nieważności małżeństwa nie jest wystarczające stwierdzenie ani jakichś braków psychicznych, które powodują trudności w życiu małżeńskim, ani istnienie cech psychicznych, które sprzyjają powstawaniu napięć pomiędzy małżonkami ${ }^{28}$.

W ślad za nauczaniem Biskupa Rzymu, sędziowie Roty Rzymskiej, zaznaczają, że w określaniu podstawy niezdolności nie można zadowolić się ukazaniem poważnych trudności w podejmowaniu obowiązków małżeńskich. Taka kategoria jest niewystarczająca ${ }^{29}$. Jak zauważa Dzierżon, praktyczna aplikacja takiej kategorii może okazać się bardzo trudna. Dokonując analizy wyroków rotalnych, wskazany autor udowadnia, że i tu występuje rozbieżność opinii. Jedni uważają, że wystarczające jest ukazanie kondycji podmiotu do istotnych praw i obowiązków małżeńskich oraz przyczyn natury psychicznej (na czym polegałaby niezdolność względna - niezdolność podmiotu do wytwo-

27 Zob. wypowiedź P i n t o z 1979 odnośnie do rozeznania oceniającego, w: J. Beal, Komentarz do kan. 1095 n. 2, w: J. Beal, J. Coriden, T. Green, New Commentary on the Code of Canon Law, New York 2000, s. 1300.

${ }^{28}$ F. P o m p e d d a, Kan. 1095 w systematyce generalnej ..., s. 42.

29 S. P a ź d z i o r, Przyczyny psychiczne ..., s. 53. 
rzenia więzi małżeńskiej w tym konkretnym małżeństwie); inni, że należy kierować się ekspertyzami biegłych; jeszcze inni, że miarodajna jest absolutność lub ciężkość owej niezdolności (co jest wyrazem odrzucenia niezdolności względnej). Dzierżon wskazuje, że wyroki rotalne zawierają następujące określenia anomalii: prawdziwa anomalia (anomalia vera), ciężka anomalia (anomalia gravis), patologiczna anomalia psychiczna (pathologica abnormitas psychica) lub ciężka patologia (pathologia gravis) ${ }^{30}$.

Pompedda w swoim referacie wygłoszonym na Międzynarodowym Sympozjum Kanonistów w Sikorzu koło Płocka w 1998 r., podkreślił, że Rota Rzymska domaga się, aby anomalia w podmiocie była: ciężka, uprzednia i trwała. Sam jednak zajął krytyczne stanowisko wobec tej tezy. Odniósł się krytycznie do ciężkości z racji na to, że anomalia zakłada w sobie w odróżnieniu od trudności wykluczenie stopniowania. Ponadto uważa - jeśli chodzi o uprzedniość albo trwałość - że wystarczyłoby, aby niezdolność została orzeczona w momencie zawarcia małżeństwa ${ }^{31}$. Wydaje się możliwe tylko od strony spekulatywnej, aby domagać się wykazania istnienia anomalii w momencie zawarcia małżeństwa. Jeśli nie występowała ona przed zawarciem małżeństwa, trudno udowodnić, że towarzyszyła ona podmiotowi w momencie ślu$\mathrm{bu}^{32}$. Domaganie się zatem przymiotu uprzedniości anomalii ma więc swój sens „dowodowy”. Wskazanie, że podmiot był dotknięty jakąś anomalią we wcześniejszym życiu (ale stosunkowo bliskim momentowi ślubu, tak że nie zdołał się z niej ,wydobyć”) i to, że miała ona charakter trwały, uwiarygodnia sentencję sędziego, że w momencie zawarcia małżeństwa $\mathrm{z}$ całą pewnością był dotknięty anomalią. Zawsze jednak wystarczające jest udowodnienie anomalii w momencie ślubu, bez odwoływania się do przeszłego życia nupturienta.

W ukazaniu podstawy relacji do istotnego obowiązku małżeńskiego oddzielną kompetencję mają biegli i sędziowie.

\subsection{Zadanie biegłego}

Istotne znaczenie w omawianej kwestii, odegrała Instrukcja z dnia 25 stycznia 2005 r. Dignitas connubii. Jej art. 209 §1 stanowi, że:

30 Zob. G. D z i e r ż o n, Niezdolność do zawarcia matżeństwa ..., s. 208-211.

${ }^{31}$ F. P o m p e d d a, Kan. 1095 w systematyce generalnej ..., s. 42.

${ }^{32}$ S. P a ź d z i o r, Przyczyny psychiczne ..., s. 55. 
„W sprawach niezdolności w myśl kan. 1095, sędzia nie może pominąc opinii biegłego dotyczącego faktu, czy strona lub obie strony w czasie małżeństwa były dotknięte jakąś szczególną anomalią, trwałą lub nietrwała; jaki był jej stopień ciężkości; oraz w jakich okolicznościach i przyczynach anomalia ta pojawiła się i jak się objawiała; $\S 2$. Szczególnie: $3^{\circ} \mathrm{W}$ sprawach dotyczących osób, które nie są zdolne podjąć istotnych obowiązków małżeńskich, należy zapytać, jaka jest natura i ciężkość przyczyny psychicznej, która sprawiła u strony nie tylko poważną trudność, ale także niemożliwość podjęcia obowiązków małżeńskich"33.

Biegły zatem ma za zadanie spojrzeć na pierwszy z trzech elementów konstytutywnych kan. 1095 n. 3, czyli na podmiot oskarżany o niezdolność i odpowiedzieć na pytanie zawarte w wyżej cytowanym artykule, czyli określić, jaka anomalia istnieje w podmiocie i jaki jest jej stopień. Do jego zadań należy także wskazanie, jak ta anomalia się pojawiła i jak się objawiała.

Dla sędziów trybunału niezwykle cennym jest ostatni element obowiązku stawianego biegłemu, który polega na dokonaniu pewnego opisu humanistycznego funkcjonowania osoby dotkniętej diagnozowaną anomalią. Samo wskazanie na naturę i stopień ciężkości dla wyrokujących o nieważności małżeństwa, $\mathrm{z}$ racji na to, że sami nie są $\mathrm{z}$ reguły biegłymi, może być nieczytelne. Stąd ważne jest wskazanie na istotne przejawy zachowania się osoby oskarżanej o niezdolność, w postaci implikacji ukazujących funkcjonowanie badanej osoby pod katem negatywnym. Chodzi o wpływ zdiagnozowanej anomalii na zdolności poznawczo-wolitywne podmiotu ${ }^{34}$. Te implikacje winny ukazywać, czego taka osoba nie jest w stanie zrobić, jakie ma główne problemy, jaką ma hierarchię wartości, jak postrzega innych itp. Oczywiście będą one kształtować się różnie, w zależności od rodzaju wskazanej anomalii.

Ilustrując wymagania stawiane biegłym, można wskazać na pewien przykład. W katalogu osobowości nieprawidłowych, przytoczonym przez J. Cymbałę, znajduje się m.in. osobowość zależna. Gdyby zatem

${ }^{33}$ T. R o z k r u t, Komentarz art. 209 Instrukcji procesowej „,Dignitas connubii”, w: T. Rozkrut (red.), Komentarz do Instrukcji procesowej Dignitas connubii, Sandomierz 2007, s. 285-287.

${ }_{34}$ G. L e s z c z y ń s k i, Wartość dowodowa opinii biegłego w procesie o stwierdzenie nieważności matżeństwa, Ius Matrimonale 9 (15) 2004, s. 143. 
biegły stwierdził taką osobowość u badanej osoby, winien w podsumowaniu swojej opinii - w rozumieniu wskazanego przepisu prawnego Dignitas connubii - zamieścić trzy rodzaje informacji. Po pierwsze, że u badanej osoby stwierdza istniejącą w momencie zawarcia małżeństwa osobowość zależną, która jest uznana naukowo za osobowość nieprawidłową. Po drugie odnieść się do stopnia tej osobowości, pisząc np., że u badanej osoby zdecydowanie przekracza ona granice normy (albo wręcz przeciwnie, że mieści się ona w normie). Po trzecie ukazać funkcjonowanie takiej osoby poprzez opis humanistyczny, pokazując w nim od strony negatywnej to, czego badana osoba nie jest w stanie zrealizować, czego nie widzi, nie rozumie, czego nie jest w stanie podjaćc. Cymbała przytacza opis funkcjonowania osoby z osobowością zależną w następujący sposób:

- zachęcanie innych lub dozwalanie im na przejęcie odpowiedzialności za swoje ważne decyzje życiowe;

- podporządkowanie własnych potrzeb potrzebom innych, od których jest się zależnym oraz nadmierne uleganie ich życzeniom;

- niechęć do stawiania nawet racjonalnych wymagań osobom, od których jest się zależnym;

- poczucie niewygody i bezradności w sytuacji osamotnienia - z powodu nadmiernej obawy przed niezdolnością do zatroszczenia się o siebie;

- nadmierna obawa przed opuszczeniem przez osobę pozostająca w bliskim związku i osamotnieniem - wobec konieczności zajęcia się swoimi sprawami;

- ograniczona zdolność podejmowania codziennych decyzji bez zbędnego radzenie się innych osób i upewniania się o słuszności podjętych decyzji;

- brak napędu, inicjatywy, samodzielności, duża męczliwość, mała zdolność do odczuwania przyjemności, poczucie niepewności, unikanie trudności, wycofywanie się z podjętych decyzji i działań, nadwrażliwość na stresy psychiczne i somatyczne ${ }^{35}$.

Ciekawe implikacje odnośnie do osobowości zależnej, które moga wpływać na relację do obowiązków małżeńskich zauważa Steuden. Uważa ona, że w przypadku nadmiernego, patologicznego uzależnienia się od jednego lub obydwojga z rodziców, strona małżeństwa może być całkowicie zależna od woli rodzica lub rodziców. Taka zależność

35 Zob. J. C y m b a ł a, Istotne obowiazki..., s. 132. 
polegać będzie mogła np. na wypełnianiu oczekiwań rodziców, nadmiernym liczeniem się z ich opinią i przestrzeganiem ustalonych przez nich norm. ${ }^{36}$ Wydaje się, że w takim przypadku, małżonek nie będzie w stanie podejmować istotnego obowiązku małżeńskiego, za jaki należy uznać wytworzenie jedynej i wyłącznej więzi małżeńskiej z drugą stroną w związku.

\subsection{Zadanie trybunału}

Wskazanie na dwa pierwsze elementy kan. 1095 n. 3, a zatem na to, że w sprawie o nieważność małżeństwa chodzi o istotny obowiązek małżeński i że podmiot tego obowiązku cechuje się istotną anomalia (wraz z opisem jego funkcjonowania) nie wyczerpuje jeszcze w całości treści wyroku sądowego. Istotną bowiem i jednocześnie wyłączną kompetencją sądu jest opisanie relacji, jaka istnieje między podmiotem, a obowiązkiem małżeńskim. W przypadku wyroku za nieważnością małżeństwa taką relację definiuje się precyzyjnie i jednoznacznie poprzez krótkie słowo: niezdolny. To słowo, w sensie ścisłym powinno pojawić się wyłącznie dwa razy w aktach procesowych: po raz pierwszy, gdy trybunał w zawiązaniu sporu pyta o to czy podmiot jest niezdolny i po raz wtóry, gdy wydaje wyrok, stwierdzający tym razem już w zdaniu oznajmującym, że osoba jest niezdolna. Nikt inny nie może dla przejrzystości materii posługiwać się nim podczas procesu sądowego.

R. Sztychmiller, w ślad za Pompeddą i Góralskim stwierdza, że: „Dla określenia ciężkości niezdolności nie wystarczą kryteria medyczne, które mają charakter pomocniczy, lecz konieczne jest wykazanie rzeczywistej niezdolności do podjęcia obowiązków małżeńskich lub przynajmniej jednego $\mathrm{z}$ nich, a tu chodzi o określenie zdolności prawnej, co leży wyłącznie w kompetencji nauki prawa i sędziów orzekających"37. Obecnie obowiązujący Kodeks, stoi na zasadzie wolnej interpretacji środków dowodowych dokonywanej przez sędziego, która pozostawia mu tym samym rolę dominującą. Wskazana zasada obejmuje więc także ocenę prawną opinii biegłego. Sędzia nie jest nią związany. Z jednej strony ma on obowiązek wyrobienia sobie pewności moralnej na podstawie faktów i dowodów (także więc na podstawie

\footnotetext{
${ }^{36}$ S. S t e u d e n, Zadania psychologa ..., s. 217.

37 J. C y m b a 1 a, Istotne obowiazki ..., s. 71.
} 
opinii biegłego). Z drugiej strony, według zasady wolnej interpretacji środków dowodowych, sędzia może w ogóle nie wziąć jej pod uwagę $^{38}$, co jednak wydaje się bardzo teoretyczne.

Może więc zdarzyć się sytuacja, w której dwa elementy z kan. 1095 n. 3 będą wydobyte w sposób zasadniczy - tzn. zostanie wskazany istotny obowiązek małżeński oraz ukazana jasno anomalia podmiotu, a sąd wyda wyrok, w którym określi, że nie udowodniono niezdolności podmiotu do podjęcia obowiązku małżeńskiego.

W praktyce trybunałów spotyka się często ocenę takiej relacji dokonaną przez biegłych, którzy wieńcząc swoją opinię, dochodzą do wniosku, że badana osoba nie jest zdolna do podjęcia obowiązków małżeńskich. Taki osąd spotyka się z różnym przyjęciem. Omawiając niniejsze zagadnienie, wydaje się ważne i konsekwentne w dokonywaniu analizy problemu, aby odnieść się i do tej kwestii. Prawodawca powszechny w cytowanym art. $209 \S 3$ Instrukcji przestrzega: „Biegły w swoim wotum winien odpowiedzieć zgodnie z własną wiedzą i przy zastosowaniu odpowiednich metod na poszczególne pytania zawarte w dekrecie sędziego; unikając stwierdzeń, które przekraczałyby jego zadania, które należą już do samego sędziego"39.

Cytowany artykuł Instrukcji, jak należy sądzić, kończy wszelkie dywagacje na ten temat, chociaż przez brak jasnego postawienia sprawy, pozostawia jakiś margines. Dla pełnej uczciwości, trzeba zaznaczyć, że wcześniej, Jan Paweł II (we wskazanej alokucji z 1987 r.) dopuścił pośrednio, w opinii biegłego możliwość wypowiedzenia się przez niego na temat ewentualnej niezdolności podmiotu. Stwierdził mianowicie, że: „sędzia kościelny nie może domagać się od biegłego osądu na temat nieważności małżeństwa; walutacja na temat nieważności małżeństwa należy wyłącznie do sędziego"40.

Autor Instrukcji nie wskazuje wprost, co rozumie pod pojęciem zadań, które „należą do samego sędziego, a których winien wystrzegać się biegły". Rozkrut, komentując tę normę prawną, uważa, że biegły powinien powstrzymać się od wydawania oceny na temat nieważności małżeństwa. Praktyka sądownictwa kościelnego pokazuje, że biegli

${ }^{38}$ G. L e s z c z y ń s k i, Wartość dowodowa opinii ..., s. 150.

39 T. R o z k r u t, Komentarz do art. 209 Instrukcji ..., s. 285-287.

40 Por. tekst polski za: T. R o z k r u t, Jan Pawet II do Roty Rzymskiej (1979 2003), Tarnów 2003, s. 116. 
nie tyle odnoszą się do nieważności małżeństwa, co raczej do ewentualnej niezdolności podmiotu do podjęcia obowiązków małżeńskich.

Kanoniści prezentują różne zdanie na temat formułowania przez biegłych tak radykalnego osądu, ich opinie na temat są podzielone. Sobański, w publikowanych przez siebie wyrokach Trybunału Katowickiego ${ }^{41}$, uważa, że biegły ma prawo do stawiania takiej tezy. Twierdzi, że biegły wypowiadając się, że osoba jest niezdolna, nie narusza kompetencji trybunału, ponieważ zadaniem trybunału jest stwierdzenie nieważności małżeństwa, a nie niezdolności podmiotu. Trudno jednak zgodzić się ze stanowiskiem tego niewątpliwie wybitnego kanonisty, $\mathrm{z}$ racji na to, że uznanie osoby za niezdolną jest równoznaczne z uznaniem małżeństwa za nieważne. Według Leszczyńskiego biegły jest zobowiązany jedynie do wydania opinii dotyczącej struktury psycho - fizycznej podmiotu w momencie zawierania przez niego małżeństwa $^{42}$. Podobnie uważa cytowany uprzednio Rozkrut. Uzasadniając swoje stanowisko, zgłasza dwa różnie merytorycznie argumenty. Po pierwsze twierdzi, że zadaniem biegłego jest wskazanie i tylko wskazanie jasnych przesłanek naukowych, na podstawie których sędziowie mają wyrobić sobie zdanie. Po wtóre uważa, że wskazywanie przez biegłego o niezdolności psychicznej podmiotu jest niesłuszne $\mathrm{z}$ tej racji, że ta mieści się formalnie we wcześniejszym stadium procesu, jakim jest postępowanie dowodowe (a tu nie należy podawać ocen), podczas gdy wyrok sędziów jest efektem ostatniego etapu procesowego, czyli dyskusji dokonywanej wyłącznie w ich gronie. Byłoby zatem niekonsekwencją, aby w materiale dowodowym znalazła się już tak radykalna ocena sytuacji podmiotu wskazująca, że jest on niezdolny osobowościowo do podjęcia obowiązków małżeńskich ${ }^{43}$.

Wskazany wcześniej, trójstopniowy klucz, zachowany przez biegłego w opinii (natura anomalii, jej stopień, opis humanistyczny), wydaje się być przejrzysty i co ważniejsze wystarczający. Sądzę, że nie ma nawet takiej potrzeby, aby biegły odniósł się do oceny postawy badanej osoby, twierdząc, że nie jest ona zdolna do podjęcia obowiązków

${ }^{41}$ Zob. np. R. S o b a ń s k i, Wyrok Sadu Metropolitalnego w Katowicach (c. Sobański) z dnia 2.12. 2005 z tytułu niezdolności do podjęcia istotnych obowiazków matżeńskich, Ius Matrimoniale 11 (17) 2006, s. 176.

${ }^{42}$ G. L e s z c z y ń s k i, Wartość dowodowa opinii ..., s. 143.

43 T. R o z k r u t, Rola biegłego w procesach kościelnych, PK 41 (1998) nr 1 - 2, s. $262,268$. 
małżeńskich. Ów klucz mieści się całkowicie w kompetencjach biegłego i jednocześnie zmusza sędziów do podjęcia wysiłku w ocenie czy tak ukazana osobowość pretenduje do uznania podmiotu za niezdolnego do małżeństwa, czy nie. Zachowanie takiego klucza przez biegłego ma także swój walor w sferze odpowiedzialności moralnej biegłego. Biegły, unikając wypowiedzi na temat niezdolności podmiotu, nie uczestniczy w odpowiedzialności za wyrok sądowy. Ponadto, zawarcie przez biegłego oceny, że nieprawidłowość jest tak dalece przekraczająca normę, że świadczy o tym, że badana osoba była w momencie zawarcia małżeństwa niezdolna do podjęcia obowiązków małżeńskich, powoduje w konsekwencji, że odpowiedzialność za ferowany wyrok staje się „rozmyta”, a czujność w dokonywaniu oceny po stronie sędziów uśpiona. Co więcej, decyzja sędziów, wskutek takiej konkluzji biegłego, może okazać się zbyt pochopna i w przypadku błędu biegłego, będzie także błędna.

W tym też sensie, warto byłoby, aby biegli powstrzymali się od oceny, że osoba jest niezdolna, chociaż taki wniosek może nasuwać się im samorzutnie i być w ich mniemaniu najtrafniejszym z wszystkich innych, będąc swoistą, ,kropką nad i”.

\section{Wnioski}

Analizowana norma wpisana do kan. 1095 n.3 zawiera trzy elementy konstytutywne. Są nimi podmiot oskarżany o niezdolność do podjęcia obowiązku, sam obowiązek, którego podmiot nie podejmuje oraz relacja do obowiązku.

W procesie kanonicznym o nieważność małżeństwa, cały materiał dowodowy zmierza do tego, aby opisać relację istniejącą między podmiotem a obowiązkiem. Taka relacja musi tyczyć istotnego obowiązku małżeńskiego. Należy mieć na uwadze relację, którą wyznacza niezdolność do podjęcia, a nie do wypełnienia obowiązku oraz relację, która polega na niezdolności obiektywnej, a nie relatywnej. Podstawą takiej wadliwej relacji jest istotna anomalia, trwająca przynajmniej w momencie zawarcia małżeństwa. Ważną rolę w jej zdiagnozowaniu pełni biegły, wskazując na jej naturę, stopień i opis humanistyczny funkcjonowania podmiotu. W przypadku wyroku za nieważnością małżeństwa taka relacja jest opisana poprzez słowo: niezdolny.

Dla przejrzystości procesu o nieważność małżeństwa, jedynie trybunał winien operować słowem ,niezdolny” i czyni to dwukrotnie: 
za pierwszym razem pyta o to w zawiązaniu sporu i po raz drugi odpowiada twierdząco w wyroku: udowodniono niezdolność osoby do podjęcia istotnych obowiązków małżeńskich i tym samym nieważność małżeństwa.

\section{Die Relation des Subjekts zur Verpflichtung im Ehenichtigkeitsverfahren von can. 1095, 3 CIC}

Der Verfasser analysiert die Norm von can. 1095, 3. Nach seiner Meinung besteht sie aus drei Elemente. Sie sind solche wie: der Subjekt, die wesentliche Verpflichtung der Ehe und die Relation zwischen ihnen. Der Verfasser stellt die These, dass die Relation die Hauptrolle spielt.

Deswegen wendet sich das Gericht, im Ehenichtigkeitsprozess von can. 1095, 3 zum Aufzeigen der Relation. In der Nichtigkeit der Ehe wird sie durch kurzes Wort beschreibt, dass der Subjekt ,unfähig“ ist.

Der kirchliche Gesetzgeber, Rechtsprechung und die Doktrin zeigen auf, dass die Relation muss: objektiv - nicht relativ sein, zur Übernehmung - nicht zur Vollfüllung der Verpflichtung sich verhalten und ihr Grundlage in der Anomalie der Persönlichkeit liegen muss.

Es steht zur Verfügung für die kirchliche Gerichte die Instruktion „Dignitas connubii“. Sie stellt von der Sachverständigen bestimmte Forderungen. Sie sollen vorstellen: „welcher Natur und welchen Schweregrades die psychische Ursache ist, aufgrund derer die Partei nicht nur an einer ernsten Schwierigkeit, sondern auch an der Unmöglichkeit leidet, jene Handlungen vorzunehmen, welche den ehelichen Pflichten innewohnen".

Für die Klarheit des Prozesses soll nur das Gericht der Begriff ,unfähig“ benutzen. Am ersten fragt es danach in der Streitfestlegung und am Ende antwortet es im Urteil. 